\title{
A Study on Shared Leadership and Positive Psychological Capitals of Teachers at Primary and Secondary Schools ${ }^{\mathrm{i}}$
}

\author{
Necati Çobanoğlu ${ }^{1}$, Fatih Bozbayindir ${ }^{2, *}$ \\ ${ }^{1}$ Institute of Educational Sciences, Gaziantep University, Turkey \\ ${ }^{2}$ Faculty of Nizip Education, Gaziantep University, Turkey
}

Copyright $@ 2019$ by authors, all rights reserved. Authors agree that this article remains permanently open access under the terms of the Creative Commons Attribution License 4.0 International License

\begin{abstract}
The purpose of this study was to measure shared leadership and positive psychological capital levels of teachers at schools and to examine the relationship between these two variables. Descriptive survey and relational research models were used in the study. The sample group of the study was comprised of 550 teachers working at primary and secondary schools at the Battalgazi and Yeşilyurt central districts of the province of Turkey during the 2017-2018 academic year. The data were acquired via Shared Leadership Scale and Positive Psychological Capital. Descriptive statistics were calculated during the data analysis stage, correlation analysis and regression analysis were used. According to the results of the study, there is a correlation between shared leadership and the positive psychological capitals of teachers at primary and secondary schools. Shared leadership at primary and secondary schools predict the positive psychological capitals of teachers and all its sub-dimensions in a statistically significant manner. It was observed as a result of the study that shared leadership and positive psychological capitals of teachers are at a high level in primary and secondary schools. It was observed that shared leadership at schools increases the positive perspectives of teachers, their expertise, sense of trust, social characteristics, their resolve to struggle against difficulties and their hope for the future. It was observed that creating a school environment based on sharing, supporting the efforts of teachers, including them in decision making processes, ensuring that they effectively contribute to all development and change efforts in the school or the solution stages of a problem as well as working in cooperation to reach the goals of the school are important so that teachers as one of the most important elements of education develop a positive psychology.
\end{abstract}

Keywords Shared Leadership, Positive Psychological Capital, Self-efficacy, Optimism

\section{Introduction}

Today, the importance of leadership for organizations to reach their goals and to put forth effective and efficient results in their studies is an indisputable fact. The employees have to fully believe in and trust the leader as they follow him/her. The belief in the leader will increase when the leader has a democratic understanding and includes his/her followers in the decision making process. The employees will strive more to be useful to the organization when they are of the opinion that they are given importance and that their opinions are valued (Şişman, 2002). Leaders who participate in the decisions for contributing to the development of their organization together with their employees are more successful (Beycioğlu, 2010; Beycioğlu and Aslan, 2007).

The meaning of the concept of "leader" has to be put forth prior to defining the concept of leadership. Leaders are individuals who guide with their orders, instructions and decisions and have the power to influence others apart from being the officials in charge (Erdoğan, 2012). Different meanings have been attributed to leadership in the past; however different meanings are ascribed to it today. In the past, leadership was associated with power-driven concepts (influential, strong, decisive), while today the leader is expressed as an individual with characteristics such as vision, courage, desire, trust, curiosity and honesty (Bennis, 1994; Toytok, 2014). Leadership is sometimes Directional finding and the leader influencing the audience to achieve the objectives of the organization (Hitt, Miller and Colella, 2006), sometimes it was prepared according to the procedures of guidance and guidance to the followers (Iyengar, 2008). leadership is concerned with direction setting, with novelty and is essential linked to change, movement and persuasion 
(Grint, Jones, Holt, \& Storey, 2016). It has been concluded as a result of studies on the concepts of leader and leadership that there are many different types of leadership. According to Kurt Lewin there are different types of leadership such as authoritarian leadership, democratic leadership and laissez faire leadership. According to Burns and Bass the types of leadership are transformational leadership and transactional leadership. It has been put forth in recent studies carried out on leadership that there are different types of leadership: instructional leadership, distributed leadership, shared leadership.

Studies with different names other than shared leadership have been ongoing since the beginning of the 1950s (Yılmaz, 2013). Gronn indicated that the concept of shared leadership was first examined in 1954 by Gibb. Barnard (1960), Cartwright (1965), Katz and Kahn (1966) and Firestone (1996) carried out studies after Gibb on the idea that leadership should be shared. Barnard (1960) worked on the idea of "cooperative systems" based onsystems that should operate in a cooperative manner. It has been emphasized that mutual cooperation and interaction between the employees will motivate them and develop a synergy. Shared leadership began to be studied more frequently in England and America starting from the 2000s.Studies related with interaction in leadership took place in England at the National College for School Leadership. Shared leadership was among the most frequently studied types of leaderships during these studies. Studies on shared leadership also continued in the States during the 2000s. The Council of Chief State School Officers in America officially approved the shared leadership understanding in schools (Jacobs, 2010).

Leadership should be re-considered, re-evaluated and re-interpreted for today's organizations. An understanding of making cooperative decisions based on a mutual understanding should be adopted in educational organizations rather than the leadership of a single person (Hoy and Miskel, 2010).The functioning of an organization should be arranged in such a structure that will open doors to very different types of leaderships in different departments or fields (Beycioğlu and Aslan 2007).Shared leadership for educational organizations means the mutual efforts put forth by different groups in the organization (teachers, administrators and other employees) for improving the organization in their own fields of expertise or in a general sense (Jacops, 2010). According to Copland (2003), school culture should be based on trust and responsibility in order to apply shared leadership effectively in educational organizations; it should be open to learning while giving importance to cooperative work. Moreover, all employees should share their opinions on techniques and methods for teaching/learning. The fields of expertise of the employees are most important areas in which they will provide the highest and the most accurate contributions. As is the case in many other fields, it is not possible to expect a single leader to solve all these problems in educational organizations. Hence, it is required that every single employee in the organization puts in an effort and expresses his/her opinions, in addition to taking responsibility and sharing leadership in such a way that will contribute to the common mind. Human capital, which is accepted as the most important capital in modern organizations, plays a key role in achieving the goals of the organization. Shared leadership behavior may have an important role in the realization of the school's objectives. Because, with the shared leadership, the teacher, which is the most important capital of the school, will be included in the development process of the school. This will increase both the professional development of teachers and the effective use of the existing capital of the school.

Capital is known among the public as money or objects that provide an income to their owners (rent, interest or profit). Capital in the field of economics is expressed as all means of production used for producing capital goods or services (Yazıc1, 1990; Tunca, 2000) or all production tools that are not inherent to nature but are produced by men (Sürmeli, 2009).Two types of capital are encountered when capital assets of the organizations are examined. These are tangible capital and intangible capital assets. Tangible capital assets make up the physical capital of organizations indicating those that can be seen from outside, those that make us perceive them as organizations as well as the first image that comes to our mind with regard to the organizations. Financial capital is another factor that can be evaluated as part of tangible assets. Self-capabilities, optimism, self-esteem of individuals, their openness to the environment, the resistance they display against problems and their hopes for the future are known as positive psychological capital which is included as parts of intangible capital (Duffy, 2013; Luthans et.al, 2008; Luthans et.al. 2007a). Positive psychology is a concept that was first put forth during the 1990's by Martin Selingman. Selingman indicated that psychology is generally involved with the abnormal aspects of mankind but that it would be best if it deals with the positive aspects that will make people stronger and normal (Keleş, 2011). Positive psychology has generally been defined as the study of the conditions and processes that contribute to the flourishing or optimal functioning of people, groups, and institutions (Gable and Haidt, 2005).

Positive psychological capital is comprised of dimensions of self-efficacy, hope, optimism, psychological resilience, trust and extroversion. Self-efficacy is the conviction or confidence of an individual about his or her abilities to mobilize the motivation, cognitive resources or courses of action needed to successfully execute a specific task within a given context.” (Akçay, 2012; Luthans and Youssef, 2004; Henry, 2004; Bandura, 1982; Stajkovic and Luthans, 1998; Harms and Luthans, 2012). When an optimist employee reaches a significant success, he/she will generalize this by considering that it is due to his/her own personal characteristics and that these characteristics 
and principles did and will lead him/her to further success. When faced with failure, the optimists would tend to conclude that failure was not due to something inherent in them but was instead something unique to that situation and a that second attempt will likely not result in failure again (Akçay, 2011; Luthans, Youssef and Avolio, 2007). Since trust is a belief that is developed mutually among the employees, it tends to determine organizational behaviors (Sargut, 2003, Sağlam Arı, 2011). Extrovert individuals are those with higher energy in comparison with introverts. They tend to influence others more quickly and positively. They are more open to positive experience and display greater sensitivity towards positive feedback, awards and praise from others. They are more optimistic towards their environment with stronger joy of life and relations with others (Costa and McCrae, 1992; Watson and Clark, 1997; Atak, 2013). When extroversion is evaluated with regard to positive psychological capital, it is expected for teachers to be more extroverted individuals. Since teaching is a profession with a strong social aspect. Extroverted individuals are defined as energetic, felicitous, lively, enterprising individuals with strong social aspects (Eryılmaz, 2014; Tösten, 2015). These are required traits for the profession of teaching. The calmness of employees under stress and pressure and their ability to develop the most rational solutions is related with their psychological resilience. Extra effort is required in such cases. Accordingly, the individual has to put in extra effort, cope with stress, examine the crisis accurately, determine and implement the best solution (Stewart, Reid and Mangham, 1997; Reivich and Shatte, 2002).

Hope is defined as a positive motivational state that is based on an interactively derived sense of successful agency and pathways for planning to meet the desired goals (Akman and Korkut, 1993; Snyder, Sympson, Ybasco, Borders, Babyak and Higgins, 1996; Snyder, Rand and Sigmon, 2002; Harms and Luthans, 2012). It can be observed in studies by Luthans (2002, 2004) that hope has significant impacts on the academic, sportive and health related performances of individuals. In general, positive psychological capital generates a positive power in the employees thereby providing an advantage for the organization.

A positive psychology in the employees is now perceived as capital for organizations. The sense of shared leadership in schools may be effective on the positive psychological capitals of teachers. Because the self-efficacy, hope, optimism, psychological resilience, trust and extroversion perceptions of teachers may be directly or indirectly affected by advancements at schools related with the fields of expertise of the teachers or in other general fields. In this regard, the relationship between shared leadership in schools and the positive psychological capital perceptions of teachers was examined. Based on this fundamental objective, answers were sought for the following questions:
1. What are the levels of shared leadership and positive psychological capital of teachers at schools?

2. Is there a statistically significant relationship between shared leadership at school and the positive psychological capitals of teachers?

3. Is shared leadership at school a significant predictor of the positive psychological capitals of teachers?

\section{Materials and Methods}

\subsection{Study Model}

Descriptive survey and relational research models were used in the study. Descriptive survey model was used for examining the levels of leadership at school and the positive psychological capital levels of the teachers; whereas relational model was used for examining the relationship between the levels of leadership at school and the positive psychological capital levels of the teachers. Descriptive survey is the term used for studies that aim to acquire data to determine certain characteristics of a group; whereas relational study is used for studies carried out to determine the relationships between two or more variables (Büyüköztürk et.al., 2010).

\subsection{Study Population and Sample Group}

The target population of the study was comprised of teachers working at the primary and secondary schools in the Battalgazi and Yeşilyurt districts of the city of Turkey. (central districts). There were a total of 5345 teachers working at the Battalgazi and Yeşilyurt districts of the city of Turkey during 2017-2018 academic year. Cluster sampling method was used in this study which is defined as selecting randomly determined groups as the sample group instead of individuals (Özen and Gül, 2007). Each school in the study population was accepted as a cluster and the schools were selected randomly to meet the requirement for the minimum number of teachers. Table 1 shows the personal variables related with the school administrators who participated in the study.

Table 1. Personal Variables of the Teachers Who Participated in the Study

\begin{tabular}{|c|c|c|c|}
\hline $\begin{array}{l}\text { Personal } \\
\text { Variables }\end{array}$ & & $\mathrm{n}$ & $\%$ \\
\hline \multirow{2}{*}{ Gender } & Male & 291 & 53,5 \\
\hline & Female & 253 & 46,5 \\
\hline \multirow{4}{*}{ Age } & $20-30$ & 57 & 10,5 \\
\hline & $31-40$ & 219 & 40,3 \\
\hline & $41-50$ & 182 & 33,5 \\
\hline & 51 and above & 86 & 15,8 \\
\hline \multirow{2}{*}{ School Type } & Primary & 275 & 50,6 \\
\hline & Secondary & 269 & 49,4 \\
\hline \multirow{3}{*}{$\begin{array}{c}\text { Level of } \\
\text { Education }\end{array}$} & Undergraduate & 473 & 86,9 \\
\hline & Graduate & 71 & 13,1 \\
\hline & Total & 544 & 100 \\
\hline
\end{tabular}


A total of $53.5 \%$ of the participants of the study were male, whereas $46.5 \%$ were female. The distributions of the participants according to age groups were $10.5 \%$ between the ages of $20-30,40.3 \%$ between the ages of $31-40,33.5 \%$ between the ages of $41-50$ and $15.8 \% 51$ and above. The distribution according to the school type was $50.6 \%$ primary schools and $49.4 \%$ secondary schools. Of the teachers who participated in the study, $86.9 \%$ were undergraduate and $13.1 \%$ were graduate alumni.

\subsection{Data Acquisition Tools}

Positive Psychological Capital Scale: The data acquisition tool known as the "Positive Psychological Capital Scale" developed by Tösten and Özgan (2015) for determining the perceptions of teachers related to their positive psychological capital was used. The scale is comprised of the following sub-dimensions: Self-efficacy (4 items), Optimism (5 items), Trust (4 items), Extroversion (5 items), Psychological Resilience (5 items) and Hope (3 items).

Shared Leadership Scale: It is a scale developed by Aslan and Ağıroğlu Bakır (2015) for determining the perceptions of teachers regarding shared leadership at their respective schools. The scale is comprised of the sub-dimensions of; Organizational Development and Cooperation (28 items), Vision Mission (7 items), Taking Responsibility (7 items), School Culture (8 items) and Organizational Facilities (5 items). The scale was prepared using 5-point Likert type response method. It was observed as a result of the validity studies for the scale that the KMO value for the exploratory factor analysis was .96; Barlett test was $.00(\mathrm{p}<.01)$; and explained variance was $63,9 \%$.

\subsection{Data Analysis}

Following the application of shared leadership and positive psychological capital scales in the field; analyses were carried out regarding the frequency and analyses of the personal variables, arithmetic averages and standard deviations, correlation analyses and regression analyses for shared leadership and positive psychological capital.

\section{Findings}

This section provides results for the analyses carried out in order to determine the relationships between shared leadership at school and the positive psychological capital perception levels of teachers and the variables. Table 2 shows the arithmetic average and standard deviation values of the teachers for the sub-dimensions of shared leadership at school and the sub-dimensions of positive psychological capital.

It can be observed upon examining Table 2 that the shared leadership perceptions of teachers is at a high level $(\overline{\mathrm{X}}=4.04)$ in the general total. "School Culture" $(\overline{\mathrm{X}}=4.22)$ was observed to have the highest score in the scale. Another dimension with the highest average in the shared leadership general total was the "Development and Cooperation" dimension indicating that the cooperation between the teachers for developing the school is high $(\overline{\mathrm{x}}$ =4.07). Even though the "Organizational Facilities" dimension included in the shared leadership scale general total had the lowest score, it still was at a "moderate" level in the general evaluation $(\overline{\mathrm{x}}=3.65)$. Another dimension with the lowest average in the shared leadership scale general total was the "Vision Mission" dimension ( $\overline{\mathrm{X}}=3.96)$ indicating the perceptions of the teachers with regard to the development and sharing of the mission and vision of the school. It can be put forth based on these findings that the shared leadership perception levels of teachers are generally at a "High" level.

Table 2. The arithmetic average and standard deviation values of the teachers for the sub-dimensions of shared leadership at school and the sub-dimensions of positive psychological capital

\begin{tabular}{|c|c|c|c|c|c|}
\hline Scales & Sub-Dimensions & $\mathbf{N}$ & Average & Standard Deviation & Level of Significance \\
\hline \multirow{6}{*}{ Shared Leadership } & Development and Cooperation & 544 & 4.07 & 0.87 & High \\
\hline & Vision-Mission & 544 & 3.96 & 0.95 & High \\
\hline & Responsibility & 544 & 4.04 & 0.82 & High \\
\hline & School Culture & 544 & 4.22 & 0.76 & High \\
\hline & Organizational Facilities & 544 & 3.65 & 1.09 & Moderate \\
\hline & General Average & 544 & 4.04 & 0.88 & High \\
\hline \multirow{7}{*}{ Positive Psychological Capital } & Self-efficacy & 544 & 4.49 & 0.60 & High \\
\hline & Optimism & 544 & 4.30 & 0.69 & High \\
\hline & Trust & 544 & 4.58 & 0.61 & High \\
\hline & Extroversion & 544 & 4.31 & 0.73 & High \\
\hline & Psychological Resilience & 544 & 4.31 & 0.67 & High \\
\hline & Hope & 544 & 4.34 & 0.65 & High \\
\hline & General Average & 544 & 4.38 & 0.66 & High \\
\hline
\end{tabular}


It can be observed upon examining Table 2 that the positive psychological capital perceptions of teachers are quite high $(\overline{\mathrm{X}}=4.38)$ in the general total. It can also be seen that Trust $(\overline{\mathrm{x}}=4.58)$ dimension has the highest score in the scale. Whereas the "Self-efficacy" dimension $(\overline{\mathrm{X}}=4.49)$ indicating the self-efficacy perceptions of teachers is another dimension with the highest average in the positive psychological capital general total. Even though the "Optimism" dimension included in the positive psychological capital scale general total has the lowest score, it can still be observed to have a "high" value in the general average $(\overline{\mathrm{x}}=4.30)$. The "Resilience" dimension indicating the determination of teachers against difficulties is another dimension included in the positive psychological capital scale general total with the lowest average value $(\overline{\mathrm{X}}$ $=4.31$ ). It can be stated based on these findings that the positive psychology capital levels of the teachers are generally at a high level.

Table 3 shows the findings for the relationship between shared leadership and the sub-dimensions of shared leadership as well as Positive Psychological Capital and the sub-dimensions of positive psychological capital.

It was determined when Table 3 is examined that there is a positive statistically significant and moderate relationship between shared leadership and positive psychological capital $(\mathrm{r}=0.42, \mathrm{p}<.05)$. Positive statistically significant and moderate relationships were determined between the development and cooperation sub-dimension of shared leadership and the self-efficacy $(\mathrm{r}=0.31, \mathrm{p}<.05)$, optimism $(\mathrm{r}=0.32, \mathrm{p}<.05)$, trust $(\mathrm{r}=0.36, \mathrm{p}<.05)$, extroversion $(\mathrm{r}=0.46$, $\mathrm{p}<.05)$, resilience $(\mathrm{r}=0.49, \mathrm{p}<.05)$ and hope $(\mathrm{r}=0.41, \mathrm{p}<.05)$ sub-dimensions of positive psychological capital. A positive statistically significant and moderate relationship was determined between the vision and mission sub-dimensions of shared leadership and the optimism $(\mathrm{r}=0.32, \mathrm{p}<.05)$, extroversion $(\mathrm{r}=0.34, \mathrm{p}<.05)$, resilience $(\mathrm{r}=0.37, \mathrm{p}<.05)$ and hope $(\mathrm{r}=0.34, \mathrm{p}<.05)$ dimensions; while a positive statistically significant and low level relationship was determined with the self-efficacy $(r=0.26$, $\mathrm{p}<.05)$ and trust $(\mathrm{r}=0.24, \mathrm{p}<.05)$ dimensions. A positive statistically significant and moderate relationship was observed between the responsibility sub-dimension of shared leadership and optimism $(\mathrm{r}=0.37, \mathrm{p}<.05)$, resilience $(\mathrm{r}=0.35, \mathrm{p}<.05)$ and hope $(\mathrm{r}=0.30, \mathrm{p}<.05)$ dimensions of positive psychological capital; while a positive statistically significant and low level relationship was determined with the self-efficacy $(\mathrm{r}=0.27, \mathrm{p}<.05)$, trust $(\mathrm{r}=0.11, \mathrm{p}<.05)$ and extroversion $(\mathrm{r}=0.27, \mathrm{p}<.05)$ dimensions. A positive statistically significant relationship was observed between the school culture sub-dimension of shared leadership and optimism $(\mathrm{r}=0.33, \quad \mathrm{p}<.05)$ dimension of positive psychological capital; while a positive statistically significant and low level relationship was determined with the self-efficacy $(\mathrm{r}=0.24, \mathrm{p}<.05)$, trust $(\mathrm{r}=0.10, \mathrm{p}<.05)$, extroversion $(\mathrm{r}=0.20, \mathrm{p}<.05)$, resilience $(\mathrm{r}=0.28, \mathrm{p}<.05)$ and hope $(\mathrm{r}=0.24, \mathrm{p}<.05)$ dimensions. A positive statistically significant and low level relationship was observed between the organizational facilities sub-dimension of shared leadership and self-efficacy $(\mathrm{r}=0.09, \mathrm{p}<.05)$, optimism $\quad(r=0.25, \quad \mathrm{p}<.05)$, trust $\quad(\mathrm{r}=0.01, \quad \mathrm{p}<.05)$, extroversion $(\mathrm{r}=0.18, \mathrm{p}<.05)$ resilience $(\mathrm{r}=0.26, \mathrm{p}<.05)$ and hope $(r=0.20, p<.05)$ dimensions of positive psychological capital.

The impact of the sub-dimensions of shared leadership on the positive psychological capitals of teachers was examined according to the perceptions of primary and secondary school teachers. For this purpose, a linear regression analysis was carried out between the sub-dimensions of shared leadership and positive psychological capital variables. The analysis results have been given in Table 4.

Table 3. Correlation table for the Shared Leadership scores of the teachers and their positive psychological capital scores

\begin{tabular}{|l|l|l|l|l|l|l|l|}
\hline & \multicolumn{1}{|c|}{$\begin{array}{c}\text { Positive Psychological Capital } \\
\text { General }\end{array}$} & Self-efficacy & Optimism & Trust & Extroversion & Resilience & Hope \\
\hline Shared Leadership General & $.42^{* *}$ & $.27^{* *}$ & $.37^{* *}$ & $.19^{* *}$ & $.34^{* *}$ & $.41^{* *}$ & $.35^{* *}$ \\
\hline $\begin{array}{l}\text { Development and } \\
\text { Cooperation }\end{array}$ & $.50^{* *}$ & $.31^{* *}$ & $.32^{* *}$ & $.36^{* *}$ & $.46^{* *}$ & $.49^{* *}$ & $.41^{* *}$ \\
\hline Vision Mission & $.40^{* *}$ & $.26^{* *}$ & $.32^{* *}$ & $.24^{* *}$ & $.34^{* *}$ & $.37^{* *}$ & $.34^{* *}$ \\
\hline Responsibility & $.36^{* *}$ & $.27^{* *}$ & $.37^{* *}$ & $.11^{* *}$ & $.27^{* *}$ & $.35^{* *}$ & $.30^{* *}$ \\
\hline School Culture & $.30^{* *}$ & $.24^{* *}$ & $.33^{* *}$ & $.10^{*}$ & $.20^{* *}$ & $.28^{* *}$ & $.24^{* *}$ \\
\hline Organizational Facilities & $.22^{* *}$ & $.09^{*}$ & $.25^{* *}$ & .01 & $.18^{* *}$ & $.26^{* *}$ & $.20^{* *}$ \\
\hline
\end{tabular}

$* *=\mathrm{p}<.01 *=\mathrm{p}<.05$

.00-.29: Low, .30-.70: Moderate, .71-1: High 
Table 4. Multiple regression analysis for the prediction of the positive psychological capitals of teachers by the sub-dimensions of shared leadership at school

\begin{tabular}{|l|l|l|l|l|l|l|l|}
\hline Variable & \multicolumn{1}{|c|}{$\mathrm{B}$} & \multicolumn{1}{|c|}{ Standard Error } & \multicolumn{1}{|c|}{$\beta$} & $\mathrm{t}$ & $\mathrm{p}$ & Binary $\mathrm{r}$ & Partial $\mathrm{r}$ \\
\hline Constant & 3.057 & 0.120 & & 25.538 & 0.000 & & \\
\hline Organizational development and cooperation & 0.297 & 0.039 & 0.471 & 7.710 & 0.000 & 0.315 & 0.284 \\
\hline Vision-mission & 0.045 & 0.032 & 0.082 & 1.399 & 0.163 & 0.060 & 0.052 \\
\hline Taking responsibility & 0.083 & 0.040 & 0.124 & 2.074 & 0.039 & 0.089 & 0.077 \\
\hline School culture & -0.043 & 0.041 & -0.061 & -1.044 & 0.297 & -0.045 & -0.039 \\
\hline
\end{tabular}

$\mathrm{R}=.517, \mathrm{R}^{2}=.268$

$F_{(5-538)}=39,351, p=.000$

As a result of the multiple regression analysis with the objective of putting forth which of the sub-dimensions of shared leadership predict the positive psychological capitals of teachers; organizational development and cooperation, vision-mission, taking responsibility, school culture and organizational facilities variables displayed a statistically significant relationship with positive psychological capital $\left(\mathrm{R}=.517, \mathrm{R}^{2}=.268\right)\left(\mathrm{F}_{(5-538)}=39.351\right.$, $\mathrm{p}=.000)$. The organizational development and cooperation, vision-mission, taking responsibility, school culture and organizational facilities variables which are among the sub-dimensions of shared leadership explain about $27 \%$ of the change in the positive psychological capital of teachers. According to standardized regression coefficients, the relative order of importance of the predictive variables on positive psychological was organizational development and cooperation $(\beta=.471)$, organizational facilities $(\beta=$ -.128), taking responsibility $(\beta=.124)$, vision-mission $(\beta=.082)$ and school culture $(\beta=-.061)$.

It was observed when the significance tests of regression coefficients were taken into consideration that organizational development and cooperation $(\mathrm{p}=.000)$, taking responsibility $(\mathrm{p}=.039)$ and organizational facilities $(p=.012)$ from among the predictive variables are significant predictors on positive psychological capital. When the relationships between predictor variables and positive psychological capital were taken into consideration, correlations were observed as $(\mathrm{r}=.315)$ with organizational development and cooperation, [ $(r=.284)$ when the impact of the other predictive variables are controlled], $(\mathrm{r}=.060)$ with vision-mission, $[(\mathrm{r}=.052)$ when the impact of the other predictive variables are controlled], $(r=.089)$ with taking responsibility, $[(r=.087)$ when the impact of the other predictive variables are controlled], ( $\mathrm{r}=$ -.045) with school culture, [(r=-.039) when the impact of the other predictive variables are controlled] and ( $\mathrm{r}=-.107)$ with organizational facilities, $[(r=-.092)$ when the impact of the other predictive variables are controlled].

\section{Conclusions}

Average and standard deviation values for the shared leadership at school and the positive psychological capital levels of the teachers were first calculated in this study examining the level of prediction of the positive psychological capitals of teachers by shared leadership at school. Correlation and regression analyses were carried out afterwards for determining the relations and prediction levels among the variables.

The perception levels of teachers for shared leadership at school and positive psychological capital were determined to be high in the study. It was determined as a result of the study that the "organizational facilities" sub-dimension of the shared leadership variable was at a "moderate” level and that all other sub-dimensions were at a "high" level. In addition, it was determined as a result of the study that all sub-dimensions of the positive psychological capital variable were at a "high" level. It was observed that there are other studies in literature (Y1lmaz, 2013; Korkmaz, 2011; Uslu and Beycioğlu, 2013; Sarıçiçek, 2014; Bakır, 2013; Aslan ve Bakır, 2015; Güler, 2016; Oruç, 2015; Sarıcı, 2015; Kelekçi, 2015; Şahin, 2013) which support the findings of this study regarding the levels of shared leadership and positive psychological capital levels of teachers. It can be put forth that the administrators have a culture of sharing their leadership in primary and secondary schools and that the general positive psychological capitals of teachers are quite high.

It was concluded in the study that there is a positive, statistically significant and moderate relationship between shared leadership at school and the positive psychological capitals of teachers. Similarly, it has been indicated in various other studies (Erdem, Kalkın and Deniz, 2016; Fineman, 2006; Çetin, Hazır and Basım, 2013; Özer et al., 2013; Kalman and Summak, 2016) that there is a relationship between positive psychological capital and shared leadership. It was reported that shared leadership at school increased with the positive psychological capitals of teachers meaning that it is positive oriented.

Data related with the prediction of the positive psychological capitals of teachers by the sub-dimensions of shared leadership at school were among the other results of this study. It was concluded that organizational development and cooperation, taking responsibility and organizational facilities variables predict positive psychological capital in a statistically significant manner. On the other hand, it was also concluded that vision-mission and school culture from among the sub-dimensions of shared leadership do not predict positive 
psychological capital at a statistically significant level. No direct study was observed in literature examining whether shared leadership predicts positive psychological capital or not. However, there are various studies and similar results on the sub-dimensions of shared leadership and the sub-dimensions of positive psychological capital. Various studies have been carried out (Kurt, 2016; Tian, 2011; Sheppard, Hurley and Dibbon, 2010) which conclude that shared leadership predicts the teacher self-efficacy sub-dimension of positive psychological capital. While there are other studies (Y1lmaz and Kurşun, 2015; Çetin, Yeloğlu, and Basım, 2013; Schermerhorn, Gardner and Martin, 1990; Mascall, Leithwood, Straus and Sacks, 2009) which conclude that shared leadership predicts the teacher optimism sub-dimension of positive psychological capital.

In the light of these findings, cooperating with administrators for developing the organization and the desire totake responsibility can be evaluated as factors which increase the positive psychological capitals of teachers. Moreover, fair distribution of the facilities of the organization can also be expressed as another factor that improves the positive psychological capitals of teachers.

Various studies were determined in literature (Y1lmaz, 2013; Oduro, 2004; Adıgüzelli, 2016; Beycioğlu, Özer and Uğurlu, 2012) indicating that shared leadership predicts teacher trust which is a sub-dimension of positive psychological capital. It was also observed in other studies (Çetin, Yeloğlu and Basım, 2015; Basım, Çetin and Tabak, 2009) that shared leadership predicts extroversion which is another sub-dimension of positive psychological capital. There were also other studies (Çetin, Yeloğlu and Basım, 2015; Çetin, Hazır and Basım, 2013) concluding that shared leadership predicts the psychological resilience of teachers which is a sub-dimension of positive psychological capital. It was also observed in various other studies (Tösten, 2015; Luthans and Jensen, 2002) shared leadership predicts hope of the teachers which is another sub-dimension of positive psychological capital.

In conclusion; it was observed that shared leadership is high at primary and secondary schools, that authorities and responsibilities are shared and that the school culture is adopted and shared. Development of the school and the employees along with an understanding of cooperation are adopted along with taking responsibility as well as the mission and vision of the school. All of these elements fairly share the opportunities and facilities of the school.

It was observed that teachers have high positive psychological capital perceptions at primary and secondary schools. The teachers trust themselves, other employees and their institutions. They have a good level of expertise and self-efficacy while carrying out their profession. They have a strong feeling of hope that they will reach the goals they desire. The teachers are extroverted with active, lively and strong sociable characteristics. They have the resilience to cope with problematic situations. They are able to think positively in both positive and negative situations.

Cooperation with other employees for developing the school, giving responsibility to administrators as well as other employees and fairly distributing the opportunities and facilities at the school predict the positive psychological capitals of teachers in a statistically significant manner due to the nature of shared leadership.

The following suggestions were developed based on these findings:

1. Shared leadership course should be obligatory for teacher candidates at universities as well as in-service trainings for working teachers in order to ensure that the characteristics of shared leadership are put forth more effectively instead of the traditional leadership approach that considers a type of leadership dominated by administrators at primary and secondary schools.

2. Since the institution can be developed only with the contribution of teachers, students, guardians and other employees, all shareholders should work in unison from the planning to the application stages in order to implement the required courses, seminars, trainings etc. in addition to providing the required tools and materials as well as education programs while also carrying out the necessary academic and social activities aimed at students.

3. The teachers are of the opinion that facilities at schools are not distributed fairly. Keeping in mind that sharing organizational facilities predicts the positive psychological capitals of teachers, the school principals should be transparent and fair when sharing these facilities which in turn will increase the positive perceptions.

4. Teachers have a weak belief that they will receive help and support from their principals when they encounter a problem. In order to increase the positive psychological capitals of the teachers, the principals should ensure that teachers believe they will always be supporting them regardless of the conditions they face. They should make the teachers feel their support when faced with a real problem.

\section{REFERENCES}

[1] Şişman, M. (2002). Öğretim Liderliği. Ankara: Pegem Yayıncilik.

[2] Beycioğlu, K. (2010). Kitap inceleme (Improving schools through teacher leadership). Kuram ve Uygulamada Egitim Yönetimi Educational Administration-Theory and Practice, 16(2).

[3] Beycioğlu, K. \& Aslan, M. (2007). The need for organizational innovations in public elementary schools. International Journal of Educational Reform, 16 (1), 27-37. 
[4] Erdoğan, İ. (2012). Eğitimde değisim yönetimi. Ankara: Pegem akademi yayınları.

[5] Bennis, W. (1994). Lider olmanın temel ilkeleri. Çev. M. Özel. Stratejik yönetim ve liderlik kitabından (ss. 63-67). İstanbul: İz yayıncilık.

[6] Hitt, M. A., Miller, C. C. \& Colella, A. (2006). Organizational behavior. A strategic approach. San Francisco: Wiley.

[7] Iyengar, G.V. (2008). High performance leadership. Global Media, Mumbai, IND, pp. 2-64.

[8] Grint, K., Jones, O. S., Holt, C., \& Storey, J. (2016). What is leadership. The Routledge companion to leadership, 3.

[9] Toytok, E. H. (2014). Öğretmen algılarına göre okul yöneticilerinin etik liderlik davranışlarının örgüt kültürü üzerine etkisi (Düzce ili örneği). (Yayınlanmamış Doktora Tezi). Abant İzzet Baysal Üniversitesi, Bolu

[10] Yılmaz, A. İ. (2013). İlköğretim Okulu Öğretmenlerinin Paylaşılan Liderlik Davranışları. (Yayınlanmamış Yüksek Lisans Tezi). Dokuz Eylül Üniversitesi Eğitim Bilimleri Enstitüsü, İzmir.

[11] Katz, D. \& Kahn, R.L. (1966). The social psychology of organizations, New York: Wiley.

[12] Firestone, W. A. (1996). Leadership: Roles or Functions? $\mathrm{K}$.Leithvvood et al., (eds.), International Flandbook of Educational Leadership and Administration, Kluwer Academic Publishers, Netherlands, ss. 395-418.

[13] Jacobs, G. E. (2010). The relationship between distributed leadership as practiced by principals and the organizational commitment of the teachers. Unpublished Doctoral Dissertation. Georgia Southern University. USA.

[14] Hoy, W. K. \& Miskel, C. G. (2010). Eğitim Yönetimi: Teori Araştırma ve Uygulama. Nobel Yayınları. Ankara.

[15] Yazıc1, M. (1990). Muhasebe Tümlemleri ve Örgütlenmesi. No: 439/672. İstanbul: MÜ İ̈BF-Nihad Sayar- Yayın ve Yardım Vakfi Yayını.

[16] Tunca Z. \& Birdal M. (2000). Yabancı Sermaye’nin Gelişme Sürecine Katkısı. İstanbul Sanayi Odası Dergisi, ss.1-1

[17] Sürmeli, F. (2009). “Genel Muhasebe”. Genel Muhasebe Kitabı Ünite 13. Anadolu Üniversitesi Yayını. No: 1341.

[18] Duffy, J. R. (2013), Quality Caring: In Nursing and Health Systems, 2nd Edition, New York: Springer Publishing Company, LLC.

[19] Luthans, F.,Avey, J. B. \& Patera, J. L. (2008), Experimental Analysis of a Web Based Intervention to Develop Positive Psychological Capital, Academy of Management Learning and Education, 7, 209-221.

[20] Luthans, F.,Youssef, C. M. \& Avolio, B. J. (2007), Psychological Capital: Developing the Human Competitive Edge, 1st Edition, New York, NY: Oxford University Press, Inc.

[21] Keleş, H. N. (2011). Pozitif Psikolojik Sermaye: Tanımı, Bileşenleri ve Örgüt Yönetimine Etkileri. Organizasyon ve Yönetim Bilimleri Dergisi, 3(2), 343-350.

[22] Gable, S. L. \& Haidt, J. (2005). What (and Why) Is positive psychology? Review of General Psychology, 9(2), 103-110.

[23] Akçay, V. H. (2012). Pozitif psikolojik Sermayenin Iş Tatmini ile Ilişkisi. Kahramanmaraş Sütçü İmam Üniversitesi İktisadi ve İdari Bilimler Fakültesi Dergisi, 1, 123-140.

[24] Luthans, F. \& Youssef, C. M. (2004). Human, social, and now positive psychological capital management: Investing in people for competitive advantage. Organizational Dynamics, 33(2), 143-160.

[25] Henry, J. (2004), Positive and Creative Organization. In Linley, P. A. and Joseph, S. (Eds.), Positive Psychology in Practice (p. 269-286). New Jersey, NJ: John Wiley \& Sons, Inc.

[26] Bandura, A. (1982), Self-efficacy Mechanism in Human Agency, American Psychologist, 37(2), 122-147.

[27] Stajkovic, A. D. \& Luthans, F. (1998), Social Cognitive Theory and Self- Efficacy: Going beyond Traditional Motivational and Behavioral Approaches, Organizational Dynamics, 26(4), 62-74.

[28] Harms, P. D. \& Luthans, F. (2012), Measuring Implicit Psychological Constructs in Organizational Behavior: An Example Using Psychological Capital, Journal of Organizational Behavior, 33(4), 589-594.

[29] Luthans, F. (2002). Positive organizational behavior: Developing and managing psychological strengths. Academy of Management Executive, 16(1), 57-72.

[30] Luthans, F.,Luthans, B. C., \& Luthans, K. W. (2004). Positive psychological capital: Beyond human and social capital. Business Horizons, 47(1), 45-50.

[31] Akçay, V.H. (2011). Pozitif Psikolojik Sermayenin Kişisel Değerler Bakımından Iş Tatminine Etkisi ve Bir Araştırma. (Yayınlanmamış Yüksek Lisans Tezi). İstanbul Üniversitesi, Sosyal Bilimler Enstitüsü, İstanbul.

[32] Sargut, A. S. (2003), "Kurumsal alanlardaki örgüt yapilarininoluşmasinda ve ekonomik işlemlerin yürütülmesinde güvenin rolü”, (Ed.) F. Erdem, Sosyal Bilimlerde Güven, Ankara: Vadi Yayınları, 89-124

[33] Sağlam Arı, G. (2011). Kadın Ve Erkek Yöneticilerin Güven Özelliklerine Ilişkin Tutumları: Varsayımsal Astlar Üzerine Bir Araştırma. Atatürk Üniversitesi Sosyal Bilimler Enstitüsü Dergisi 201115 (1): 105-120

[34] Watson, S. T. (2005). Teacher collaboration and school reform: distributing leadership through the use of professional learning teams. Unpublished Doctoral Dissertation, The Faculty of The Graduate School University of Missouri-Columbia, USA

[35] Atak, H. (2013). On-Maddeli Kişilik Ölçeği'nin Türk Kültürü’ne Uyarlanması. Nöropsikiyatri Arşivi, 50, 312-319.

[36] Eryılmaz, A. (2014). Herkes için Mutluluğun Başucu Kitabı Teoriden Uygulamaya Pozitif Psikoloji. Ankara: Pegem Akademi

[37] Tösten, R. (2015). Öğretmenlerin pozitif psikolojik sermayelerine ilişkin algılarının incelenmesi (Yayınlanmamış Doktora Tezi). Gaziantep Üniversitesi, Gaziantep. 
[38] Stewart, M. Reid, G. \& Mangham, C. (1997), Fostering Children's Resilience, Journal of Pediatric Nursing, 12(1), 21-31.

[39] Reivich, K. and Shatte, A. (2002), The Resilience Factor: 7 Keys to Finding Your Inner Strenght and Overcoming Life's Hurdles, New York, NY: Broadway Books.

[40] Reivich, K. \& Shatte, A. (2002), The Resilience Factor: 7 Keys to Finding Your Inner Strength and Overcoming Life's Hurdles, New York, NY: Broadway Books.

[41] Akman, Y. \& Korkut, F. (1993). Umut Ölçeği Üzerine Bir Çalışma. Hacettepe Üniversitesi Eğitim Fakültesi Dergisi. 9, 193- 202.

[42] Snyder, C. R.,Sympson, S. C., Ybasco, F. C., Borders, T. F., Babyak, M. A., \& Higgins, R. L. (1996). Development and validation of the state hope scale. Journal of Personality and Social Psychology, 70, 321-335.

[43] Snyder, C. R.,Rand, K. L. and Sigmon, R. S. (2002), Hope Theory: A Member of the Positive Psychological Family. In Snyder, C. R. and Lopez, S. J. (Eds.), 168 Handbook of Positive Psychology (p. 257-276), New York, NY: Oxford University Press.

[44] Büyüköztürk, Ş., Çakmak, E. K., Akgün, Ö. E., Karadeniz, Ş. \& Demirel, F. (2010). Bilimsel Araştırma Yöntemleri. 7. Baskı Ankara: Pegem Akademi Yayınları.

[45] Özen, Y. \& Gül, A. (2007). Sosyal ve Eğitim Bilimleri Araștırmalarında Evren-Örneklem Sorunu. Kazım Karabekir Eğitim Fakültesi Dergisi, 15, 394- 422.

[46] Korkmaz, E. (2011). İlköğretim okul yöneticilerinin paylaşımcı liderlik davranışlarını gösterme düzeyleri. (Yayınlanmamış Yüksek Lisans Tezi). Sakarya Üniversitesi, Sakarya.

[47] Uslu, B. \& Beycioğlu, K. (2013). İlköğretim Okulu Öğretmenlerinin Örgütsel Bağlılıkları Ile Müdürlerin Paylaşılan Liderlik Rolleri Arasındaki Ilișki. Ondokuz Mayıs Üniversitesi Eğitim Fakültesi Dergisi, 32(2), 323-345

[48] Sarıçiçek, L. (2014). Gaziantep Ili Şehitkamil Ilçesindeki Ilkokullarda Öğretmen Görüşlerine Göre Paylaşılan Liderlik ve Okul Iklimi. (Yüksek Lisans Tezi). Gaziantep Üniversitesi, Gaziantep.

[49] Bakır, A. A. (2013). Öğretmenlerin Paylaşılan Liderlik Ve Örgütsel Bağlılık Algıları Arasındaki Ilişkinin Analizi. (Yayınlanmamış Doktora Tezi). İnönü Üniversitesi, Malatya.

[50] Aslan, M. \& Ağıroğlu Bakır, A. (2015). Okul örgütlerinde paylaşılan liderlik ölçeği: Geçerlik ve güvenirlik çalışması. Kuram ve Uygulamada Eğitim Yönetimi. 21 (1), 1-24

[51] Yılmaz, A. İ. (2013). İlköğretim Okulu Öğretmenlerinin Paylaşılan Liderlik Davranışları (Yayınlanmamış Yüksek Lisans Tezi). Dokuz Eylül Üniversitesi Eğitim Bilimleri Enstitüsü, İzmir.

[52] Güler, G. (2016). Pozitif psikolojik sermaye ile örgütsel bağlılık ilişkisi: mersin ili perakende sektörü çalışanları üzerine bir araştırma. (Yayınlanmamış Yüksek Lisans Tezi). Toros Üniversitesi, İstanbul.

[53] Sarıcı, D. (2015). Öğretmenlerin Iş Doyumu Ile Pozitif Psikolojik Sermaye Düzeylerine Yönelik Görüșleri (Izmir-
Foça Ilçesi Örneği). (Yayınlanmamış Yüksek Lisans Tezi). Abant İzzet Baysal Üniversitesi, Bolu.

[54] Kelekçi, H. (2015). Öğretmenlerin Pozitif Psikolojik Sermayeleri Ile Yeterlik Inançları Arasındaki Ilişki (Yayınlanmamış Yüksek Lisans Tezi). Dumlupınar Üniversitesi, Kütahya.

[55] Şahin, İ. (2013). İlköğretim Okul Müdürlerinin Okul Geliştirme Stratejileri ve Uygulamalarına Ilişkin Görüşleri. Kuram ve Uygulamada Ĕgitim Bilimleri Dergisi. 13(1), 229-250.

[56] Erdem, H., Kalkın, G. \& Deniz, M., (2016). Kişilik Özelliklerinin ve Kontrol Odağının Psikolojik Sermaye Üzerine Etkisi. Gümüşhane Üniversitesi Sosyal Bilimler Enstitüsü Elektronik Dergisi 7(16), 26-43.

[57] Fineman, S. (2006). On being positive: Concerns and counterpoints. Academy of Management Review, 31, 270-291.

[58] Çetin F., Hazır K. \& Basım H. N. (2013). Destekleyici Örgüt Kültürü ile Örgütsel Psikolojik Sermaye Etkileșimi: Kontrol Odağının Aracılık Rolü. H.Ü. Íktisadive Idari Bilimler Fakültesi Dergisi, 31(1), 31-52.

[59] Özer, S. P., Topaloğlu, T. \& Özmen, Ö. N. T. (2013). Destekleyici Örgüt Ikliminin, Psikolojik Sermaye ile Iş Doyumu Ilişkisinde Düzenleyici Etkisi. Ege Academıc Revlew, 13 (4), 437-447.

[60] Kalman, M. \& Summak, M. S., (2016). Öğretmenlerin Psikolojik Sermayelerinin Geliştirilmesine Yönelik Bir Karma Yöntem Araştırması. Gaziantep University Journal of Social Sciences, 5(1), 27-58.

[61] Kurt, T. (2016). Öğretmen Liderliğini Açıklamaya Yönelik Bir Model: Dağıtımcı Liderlik, Örgütsel Öğrenme ve Öğretmenlerin Öz Yeterlik Algısının Öğretmen Liderliğine Etkisi. Eğitim ve Bilim Dergisi, 41 (183), 1-28.

[62] Tian, M. (2011). Distributed Leadership and Teachers' self-efficacy: The case studies of Three Chinese Schools in Shanghai. Master's Degree Programme in Educational Leadership.

[63] Sheppard, B., Hurley, N. \& Dibbon, D. (2010). Distributed Leadership, Teacher Morale, and Teacher Enthusiasm: Unraveling The Leadership Pathways to School Success. Annual Meeting of the American Educational Research Association, Denver, Colorado.

[64] Y1lmaz, E. \& Kurşun, A. T. (2015). Okul Kültürü Ile Akademik Iyimserlik Arasındaki Ilişki. Mehmet Akif Ersoy Üniversitesi Eğitim Fakültesi Dergisi, 35, 46 -69.

[65] Çetin, F., Yeloğlu, H. O. \& Basım, H. N. (2015). Psikolojik Dayanıklılığın Açıklanmasında Beş Faktör Kişilik Özelliklerinin Rolü: Bir Kanonik Ilisski Analizi. Türk Psikoloji Dergisi, 30 (75), 81-92.

[66] Schermerhorn, J.R., W.L. Jr Gardner \& T.N. Martin (1990) Management Dialogues: Turning on the Marginal Performers, Organizational Dynamics, 18, 47-59.

[67] Mascall, B.,Leithwood, K., Straus, T., \& Sacks, R. (2009). The relationship between distributed leadership and teachers' academic optimism. In A. Harris (Ed.), Distributed school leadership (pp.81-100). Dordrecht: Springer Press. 
[68] Oduro, G. K. T. (2004). Distributed leadership in schools: What English head teachers say about the pull and push factors. Paper presented at the British Educational Research Association Annual Conference, Manchester, UK. Retrieved from http://www.leeds.ac.uk/educol/documents/ 00003673.htm

[69] Adıgüzelli, Y. (2016). Dağıtılmış Liderlik Ile Örgütsel Güven Arasındaki Ilişkinin Öğretmen Görüşlerine Göre Incelenmesi. Eğitim ve Bilim, 41(185), 269-280.

[70] Beycioğlu, K., Özer, N. \& Uğurlu, C. F. (2012). Distributed Leadership and Organizational Trust: The Case of Elemantary Schools, Procedia-Social and Behavioral Sciences, 46, 3316-3319.

[71] Basım, H. N., Çetin \& F., Tabak, A. (2009). Beş Faktör Kişilik Özelliklerinin Kişilerarası Çatışma Çözme Yaklaşımlarıyla Ilişkisi. Türk Psikoloji Dergisi, 24(63), 20-34.

[72] Luthans, F., \& Jensen, S. M. (2002). Hope: A New Positive Strength for Human Resource Development. Human Resource Development Review, 1, 304-322.

i This study was produced from the ongoing thesis entitled "A Study On Shared Leadership and Positive Psychological Capitals of Teachers at Primary and Secondary Schools". 